\title{
Is there a bubbly euphoria in the Turkish housing market?
}

\author{
Yener Coskun ${ }^{1}$ (D) . Charalambos Pitros ${ }^{2}$
}

Received: 13 February 2019 / Accepted: 14 January 2022 / Published online: 17 February 2022

(c) The Author(s), under exclusive licence to Springer Nature B.V. 2022, corrected publication 2022

\begin{abstract}
The purpose of this paper is to examine whether there is a bubble in the Turkish housing market during the period of 2006-2018. In conjunction with the irrational bubble theory, this study applies the Pitros and Arayici (Int J Hous Mark Anal 9(2):190-221, 2016. 10.1108/IJHMA-01-2015-0002) bubble algorithmic model. The empirical results reveal that the Turkish housing market was in a bubble during 2013-2017 period, the peak/last year of the bubble is the year 2017 and that the bubble-bust occurred in 2018. The foremost contribution of this study is that it is the first to document a historical housing bubble episode for Turkey using the premises of irrational bubble theory and the first to apply an algorithmic approach to assess the bubble risk for the period of 2006 and 2018. As to the implications, this documented model may be used as a tool to enhance policymakers' knowledge toward the early identification of housing bubbles.
\end{abstract}

Keywords Housing · Bubble $\cdot$ Behavioral economics · Turkish housing market · Algorithmic model

JEL Classification R31 $\cdot$ E44 $\cdot$ G01

\section{Introduction}

Literature reveals that financial and real estate bubbles are not new phenomena. In addition to well-known bubble episodes such as, seventeenth and eighteenth century bubbles in Holland (Tulipmania), in England (South Sea bubble), and in France (Mississippi bubble), Bell et al. (2018) found the presence of periodic, partially collapsing speculative bubbles in the market for agricultural land in England during the period of 1308 and 1508. The role of

Yener Coskun

ycoskun@spk.gov.tr

Charalambos Pitros

charalambos.pitros@aucy.ac.cy

1 Capital Markets Board of Turkey, TED University, Ankara, Turkey

2 Faculty of Business Administration and Economics, Department of Management and Marketing

— Real Estate Management, American University of Cyprus (AUCY), Larnaca, Cyprus 
price inflation of properties in the 1929 Crisis is still in question (see, Glaeser, 2013), but Global Financial Crisis (GFC) of 2008 clearly reveals that property bubbles may trigger a full-fledged financial crisis in a global scale. Bubbles generally follow an interesting psychological path with various behavioral patterns arising from personal perceptions to social hysteria. As mostly observed, short-sighted politics and mainstream media, perhaps unintentionally, support the evolving of bubble. This market psychology may create an artificial price structure and a marketplace for (non-) financial assets. Literature suggests that bubble psychology also works in real estate observed as the skyrocketed prices during Japan's property bubble in 1990's, Asian Financial Crisis (1997-1998) and US subprime mortgage crisis (2007-2010). GFC implies that developed countries may be more prone to property bubbles, but empirical literature also suggests that emerging economies may face some property bubble cases, as well. Turkey has long been in the spotlight of housing bubble analysts. This study explores whether bubble concern in Turkey has a reliable background. The aim of this paper is to assess the prevailing bubble risk for the Turkish housing market by utilizing data sets for the period of 2006-2018. To this end, our analysis is intended to either reject the claim of the presence of a housing bubble or confirm on an ex-post basis its presence, or alternatively identify an on-going bubble for the Turkish housing market.

Turkish housing market deserves more attention for some reasons. First, Turkey has the largest housing market in Europe in terms of house sales volume during 2015 and 2018 period except Russia (Hypostat, 2019) and perceived as the successful growth story as the emerging housing market in recent years (see, Coskun, 2011). More importantly, as the motivation of the study (see, "Appendix 2"), we also choose Turkey due to an interesting paradox. The fundamentals may intuitively suggest a justification for the recent house price inflation, however, several other metrics spark fears that a bubble may be present. Growing transaction motives in Turkish housing market have resulted in a dramatic rise in demand, supply, leveraged sales, and prices in recent years. Some parts of this booming market would be related to environmentally/socially disturbing rent-seeking activities and create even low-tax profit heaven for some market participants such as constructors/ developers, investors, and brokers. However, it is difficult to imagine the percentage and the whole impacts of this speculative framework, irrational bubble theory, pursued in this study, may provide a different quantitative analysis perspective to understand bubble risk in the Turkish housing market despite optimistic views based on the positive perceptions of "fundamentals".

Consequently, we utilize a new algorithmic technique as proposed by Pitros and Arayici (2016) to put in the epicenter of analysis the synchronized performance and the acceleration rate of certain indicators to assess the probability of a bubble. This dating algorithm model does not treat as its epicenter of analysis the variable representing house prices, or any other sole variable in bubble analysis. Instead, it has been developed and it places emphasis on estimating the magnitude of the phenomenon as a whole. Therefore, it purely represents the bubble without commingling with any fundamental aspect of pricing. Hence, what differentiates our method from most conventional bubble techniques is that instead of using fundamental variables to explain prices that in turn will somehow explain bubbles, we use the inherent symptoms of bubbles to explain directly the bubble component in the Turkish housing market (Pitros, 2016; Pitros \& Arayici, 2016).

The contribution of this study is twofold. Firstly, to the best of our knowledge, this paper is the first study that attempts to identify housing bubble in Turkey by relying on the irrational bubble theory (also see, Pitros et al., (2016) for the preliminary version of this study). Secondly, this is the first study in Turkey to apply an algorithmic approach to assess the bubble risk for the period of 2006 and 2018, an alternative to the mainstream (rational 
and) fundamental value approach; in which its unreliability and its serious limitations has become increasingly obvious (see, among others, Stiglitz, 1990; Shiller, 1992; Krainer \& Wei, 2004; Glaeser \& Gyourko, 2007; Orrell and McSharry, 2009; Budd, 2011). This is an important step because the algorithmic approach has been solely constructed to serve the purpose of analyzing bubbles as a phenomenon, instead of focusing on the premises of forecasting/estimating what the fundamental housing prices should be in the marketplace and then comparing them with the actuals. In this respect, all previous quantitative studies to examine the bubble question in the Turkish housing market have been approached by exploiting the premises of the efficient market hypothesis; rational bubble theory and in extent they have relied on some sort of fundamental value method.

This paper is organized as follows. Section 2 is devoted to literature review. Section 3 presents data information and modeling strategies. Section 4 presents empirical findings and implications. Finally, Sect. 5 concludes. The study has two appendixes. We present data information and supply/demand side speculations with an overview for the Turkish housing market in "Appendix 1" and "Appendix 2", respectively.

\section{Literature review}

Defining housing bubble is difficult by every means. Theoretical/empirical literature suggest that the definition/measurement methodologies differ in housing bubble (Chen et al., 2013; Joebges et al., 2015). Below, we review the dynamics and empirical outcomes of bubble models by broadly utilizing/updating Pitros (2016) by also developing a housing bubble literature review for Turkish housing market.

As the frequently used conventional housing bubble detection methodology, the descriptive statistic-ratio approach makes use of several statistical tools and ratios and may also involve surveys. Most often, these ratios are expressed as affordability measures (e.g., house-price to income, house-price to rent, mortgage payment to income, etc.) (see, among others, Case \& Shiller, 2003; Hlaváček \& Komárek, 2009; Hou, 2009; Bourassa et al., 2019). However, the extensive use of ratios tends to misjudged the bubble assessment particularly if the ratios are used alone.

Second, fundamental value modelling (single equation) is the most used bubble detection method in a housing market. Existing studies using the single-equation approach have tested whether housing prices are supported by fundamentals or whether they are temporarily deviating from what should be according to a model of fundamentals. In this respect, using OLS method on four different spatial units, Chung and Kim (2004) found evidence of bubble-like behavior in the Korean housing market. Haines and Rosen (2007) used a simple regression model to determine whether a bubble existed in the US property market. By employing two regression models, Cadil (2009) found that Czech housing market was in a speculative demand bubble. Kohn and Bryant (2010) proposed a multiple linear regression model using six independent variables. Using Gregory-Hansen method of cointegration, da Nóbrega Besarria et al. (2018) found bubble in housing prices in Brazil. Anundsen (2019) found that deviation between actual and fundamental house prices in the US during 2000s can be attributed to the explosion in subprime lending and the sharp increase in the US current account deficit. Tsai (2019) suggested that the U.K.'s house price deviation has the greatest impact on the other European housing markets, whereas France's house price deviation was the most affected by the other housing markets. 
Black et al. (2006) proposed an advanced procedure of a time-varying present value approach to assess whether house prices deviate relative to fundamental house prices. It used UK housing data from Q4 1973 to Q3 2004. The present value model estimated that UK house prices were overvalued by as much as $25 \%$ at the end of the sample period (September, 2004). Cameron et al. (2006) also used a fundamental value model to examine UK housing bubbles. This model used data from the period of 1972-2003. The period between 1972 and 1996 was used to build the model's estimation, while the period between 1997 and 2003 was used for forecasting purposes. The results suggest that in 2003, house prices were not substantially overvalued. Revisiting this study, Muellbauer and Murphy (2008) suggested that by mid-2007, UK house prices looked slightly overvalued. Using an assetpricing approach, Hou (2009) concluded that house prices were abnormal in Beijing and that the deviation from the fundamental value reached almost 30\% in 2005 and around $40 \%$ in 2007. By applying simple asset-pricing model (i.e., dividend discount model), Weeken (2004) found that housing dividends are difficult to estimate and that asset-pricing models face several limitations. Mao and Shen (2019) found that the most important fundamental, real income, cannot completely justify the housing price inflation in China. The limitations of the fundamental value models are also extensively reported in a number of other studies (see, among others, Stiglitz, 1990; Shiller, 1992; Krainer \& Wei, 2004; Glaeser \& Gyourko, 2007; Orrell and McSharry, 2009; Budd, 2011).

Another form of the single equation approach is the equilibrium model. Equilibrium models are based on the fundamental assumption that an equilibrium point exists within the housing market and that the expected annual cost of owning a house should not exceed the annual cost of using it. In this analysis, defining deviation from equilibrium is important. Lai and Van Order (2010) suggested that deviation of house prices relative to rent prices may result in the formation of bubble risk. Hott (2012) found that house price deviation is explained by herd behavior. By using simple user cost equilibrium model, Girouard et al. (2005) examined 18 OECD countries, over the period of 1970-2005 and concluded that evidence of a housing bubble in the UK appeared in the early 2000s. Similarly, Barrell et al. (2004) found that house prices in the UK in 2003-2004 were around 30\% above their equilibrium level. Ayuso and Restoy (2003) elaborated a user cost model and found for the UK that the price-to-rent ratio was around $20 \%$ above its equilibrium level. Himmelberg et al. (2005) applied a user cost approach to assess the state of house prices and concluded that in the late 1980s, the cost of owning looked quite high relative to incomes or the cost of renting and thus, a bubble existed. However, in 2004, these same measures show little evidence of housing bubbles in almost all US states. By using OLS, Granger causality and VECM models for Australia, Wang et al. (2018) found existence of long-term equilibrium in Australia housing market and thus rejected the presence of bubble.

The next category refers to the econophysic approach of the Log-Periodic Power Law (LPPL), as proposed by Zhou and Sornette (2003). Their approach involves determining of faster-than-exponential growth from the perspective of log periodic power. These signals had been found to be consistent predictors of previous crashes in financial markets. The paper concluded UK real estate market was exhibiting an ultimately unsustainable speculative bubble in 2000-2003. However, Cameron et al. (2006) suggested that this approach relies only on house prices and ignores remaining fundamental factors. Following this logic, Geraskin and Fantazzini (2011) argued that the original LPPL model was created for financial assets such as stocks rather than for housing and implementing model to housing requires additional assumptions (also see, Brée \& Joseph, 2013; Gustavsson et al., 2016).

As the final category, the algorithmic modeling approach explicitly integrates irrational bubble theory and thus it fulfills the need as raised by Greenspan (2015) of incorporating 
nonrational intuitive human responses in the models. One interesting study that uses an algorithmic approach to test housing bubbles is that of Bordo and Jeanne (2002). In their study, they identified housing boom if the three-year moving average of the growth rate of the inflation-adjusted asset price falls outside a specified range. The width of the range is defined taking into account the historical average growth rate and volatility of the asset price. Another algorithmic approach is that of Pitros and Arayici (2016). The authors suggested that the presence of the housing bubble is confirmed once the output of the model is equal or above the pre-established threshold of 0.85 . For detecting housing bubble, the methodology adopted by Tajani et al. (2019) involves a genetic algorithm to identify the best functional relationships among the variables selected, and the data sample has been obtained by considering the main variables identified in the reference literature.

There is a growing literature to date for the housing bubble in Turkey. By employing several OLS models, Erol (2015) suggested that Turkish housing market was not in a bubble during July 2007 and December 2012. IMF (2017) suggested that a presence of possible pricing excesses on the supply side in Turkish housing market. By using annual/monthly price-to-income and monthly price-to-rent ratios, Case and Shiller (2003) and an extended Case and Shiller (2003) regressions and the Right Tail Augmented Dickey-Fuller (Rtadf) test, Coskun and Jadevicius (2017) argued that neither affordability ratios nor regression estimates support the existence of the bubble in Turkey for the period of 2010 and 2014. But authors also noted potential overvaluations. Employed bubble algorithmic model of Pitros and Arayici (2016) as the preliminary empirical exercise of this study, Pitros et al. (2016) found based on irrational bubble theory that there is a serious housing bubble in the Turkish housing market during 2011 and 2015 period. By applying the methodology of Chen et al. (2017), Cagli (2019) found that nationwide house price indices in Turkey exhibited explosive behaviors during 2010-2017. Utilizing Sup-ADF and the Generalized Sup-ADF tests, Iskenderoglu and Akdag (2019) found house price bubble in Turkey during 2010-2018. Utilizing Bound test, OLS/FMOLS/DOLS, Kalman filter, and ARIMA models for the periods of 2010-2014 and 2007/6-2014, Coskun et al. (2020) explored in a rational bubble approach whether rising house prices have been justified by fundamentals in Turkish housing market. The results imply that Turkish housing market has experienced some cases of overvaluation, but not bubble formation. Duran and Özdoğan (2020) investigated the dynamics behind the regional housing prices in Turkey over a period 2010-2016 and found that speculative increase in housing prices is quite important.

Overall, housing bubble studies for Turkish housing market have used rational bubble approaches and essentially focused on house price variable. Therefore, our study fills the gap in the existing literature by being the first to exploit the irrational bubble theory for Turkish housing market and the first to apply an algorithmic approach after Pitros et al. (2016) as the preliminary empirical exercise of this study.

\section{Data and modelling strategies}

\subsection{Data description, construction and limitations}

This study adopts the bubble algorithmic model of Pitros and Arayici (2016) to Turkish housing market. The source, description and construction of the data are summarized in "Appendix 1". 
This research is subject to a series of limitations due to its novel application to the context of the Turkish housing market. The key limitations encountered in the course of the study were related to data constraints. First, instead of using first time buyers' data for the calculation of debt-burden (D/B) ratio as suggested in Pitros and Arayici (2016), we used overall market data due to data constraints. As the main inputs of this ratio, gross lending and yearly credit users (and hence remaining derived data) involve the information of whole mortgage users. Therefore, our D/B ratio reflects the conditions of an average mortgage borrower who can realistically qualify a mortgage loan in Turkey. Hence, via this method we offer a basic measurement of D/B ratio's trend that in turn is allowing us to calculate its speed of change while at the same time our proposed D/B ratio reflects the existing conditions of the Turkish housing market.

Second, average maturity of housing loans (AMHL) data obtained from Garanti Mortgage BBVA, a leading private mortgage credit issuer in Turkey, due to lack of readily available precise official data. This transaction-based nuanced data is also in line with the existing studies (i.e., TBAT, 2012; Cerutti et al., 2015). Moreover, because housing credit is generally fixed term in Turkey (see, Cerutti et al., 2015), we assume that average mortgage debt/AMHL ratio represents average mortgage payment. Third, because mostly top 5-10\% income groups have access to formal mortgage finance in Turkey (see, Coskun, 2015), we used median income last decile (10\%) data as the average income variable. This variable choice is both realistic and also conservative for our calculation. It basically represents the socio-economic center of the possible speculative housing demand in Turkey.

Fourth, because it was impossible to comprehensively identify the "Turkish bubble rule" due to the absence of historical bubble data, we considered plausible to use the existing rule of the original study, Pitros and Arayici (2016), with the view to assess whether that rule is applicable to other markets, like Turkey. One reason that supports the adoption of the original rule in this study can be pictured by the following argument. The original rule, has been constructed with reference to the UK housing market and is a by-product of the speed of change (percentage change). In turn, the speed of change is commonly used as a mode to assess the market activity in the marketplaces. Following this logic, the speed of change lends an equivalent metric when different regions are tested without imposing significant bias. To expand this further, the level of the speed of change of the selected variables, in different countries, on a bubbly period may not differ significantly; given that irrational interactions in different market places may be homogeneous and equivalently limited in propensity.

Finally, as a general concern, like other studies in the bubble literature, our data, variable selection/construction, and methodology may also not fully address the complexity of housing market (see, Grybauskas and Pilinkienè 2018). There are probably unknown number of variables that move in the same velocity with the selected variables during each phase of the market (i.e., recession, recovery, expansion or bubble) (Pitros, 2016). Also, representative power of the selected variables maybe limited due to some inherent constraints. For example, it is difficult argue that aggregate level house prices reflect locational/neighborhood nuances or housing completions fully show existing supply without a lag. Some similar arguments may be also possible for the remaining employed variables from different perspectives.

\subsection{Model inputs}

Table 1 reports the numerical data sets used in this study for the period between 2006 and 2018. The year 2006 is not available in the Table since it represents the commencing year for calculating year-over-year (YoY) percentage change. All variables are 
Table 1 Model inputs (2007-2018)

\begin{tabular}{|c|c|c|c|c|c|c|}
\hline Year & House price $(\%)$ & $\begin{array}{l}\text { Debt-burden } \\
(\mathrm{D} / \mathrm{B}) \text { ratio } \\
(\%)\end{array}$ & Gross lending (\%) & $\begin{array}{l}\text { Housing } \\
\text { completions } \\
\text { (\%) }\end{array}$ & Income $(\%)$ & $\begin{array}{l}\text { House price to } \\
\text { income ratio } \\
\text { (HPI) }\end{array}$ \\
\hline & $\alpha$ & $\beta$ & $\gamma$ & $\delta$ & $\varepsilon$ & $\lambda$ \\
\hline 2007 & 10.9 & 16.4 & -0.4 & 10.5 & 13.9 & 7.1 \\
\hline 2008 & -4.5 & -2.3 & -1.1 & 9.4 & 6.8 & 6.3 \\
\hline 2009 & -6.3 & -5.1 & 38.2 & 31.5 & 14.9 & 5.2 \\
\hline 2010 & 7.4 & -7.2 & 49.9 & -8.6 & -0.8 & 5.6 \\
\hline 2011 & 10.1 & -14.8 & -6.5 & 29.6 & 11.7 & 5.5 \\
\hline 2012 & 16.3 & -0.4 & -4.3 & -0.1 & 11.4 & 5.7 \\
\hline 2013 & 16.9 & -12.6 & 77.0 & 30.6 & 13.5 & 5.9 \\
\hline 2014 & 18.9 & 5.8 & -27.5 & 7.1 & 9.3 & 6.4 \\
\hline 2015 & 19.4 & -3.4 & 28.1 & -5.7 & 14.5 & 6.7 \\
\hline 2016 & 16.5 & 1.0 & 22.0 & 2.9 & 14.4 & 6.8 \\
\hline 2017 & 11.3 & 5.4 & 19.9 & 10.5 & 7.6 & 7.1 \\
\hline 2018 & 8.0 & -5.6 & -42.7 & 7.2 & 12.8 & 6.8 \\
\hline
\end{tabular}

measured in their annual YoY percentage change; except house price-to-income (HPI) ratio, which is employed in its annual nominal value form.

While our analysis reveals stable average increases of $10.4 \%$ and $10.8 \%$ per annum during 2007-2018 period for house price and median income accordingly; the remaining variables generally show significant volatilities. With regards to housing completions, generally a positive trend has been observed, which became remarkably irrational in 2009 and 2013 having $31.5 \%$ and $30.6 \%$ increases, respectively. Not surprisingly, this may be related to growing supply-side construction speculation thanks to positive market environment perception (see, "Appendix 2"). Even in the collapsing year of 2018, housing completion showed a 7.2\% increase. Mueller and Pevnev (1997) and Baum and Hartzell (2012) note that building development activity in housing markets increases during a bubble. Developers are always more incentivized to invest in the construction sector (i.e., supply) when prices are rising (or when they exceed construction costs). In support of this, Holcombe and Powel (2009) and Baum and Hartzell (2012) note that the quantity of houses built often can be described as the quantity dimension of bubbles.

$\mathrm{D} / \mathrm{B}$ ratio has showed significant volatilities thanks to variations in its components, namely, gross lending, yearly mortgage users, and average mortgage maturity. In this respect, one may speculate that dramatic volatilities in gross lending and yearly mortgage users variables would support speculative environment. For example, data suggest that gross lending and yearly mortgage users have increased $77 \%$ and $60 \%$ in 2013 and then declined $27.5 \%$ and $35.6 \%$ in 2014 , respectively. Then, both variables have literally collapsed in 2018 which may be intuitively suggest the bust of the bubble. Namely, gross lending (yearly credit users) declined from 68.4 billion TL (495,563 credit users) to 39.2 billion TL ( 281.873 credit users) in 2018 . As another component of $\mathrm{D} / \mathrm{B}$ ratio, average mortgage maturity (AMM) was 7.03 years during the observation period while also showed significant volatility. As the worst/best values, AMM was 5.52 years in 2009 and 7.70 years in 2013, and then declined to 7.10 years in the bust year of 2018 . 
On the other hand, house price to income (HPI) ratio has increased during 2009-2017 and then declined in the bubble bust year of 2018.

In "Appendix 2", we broadly discuss anecdotal evidences of the supply/demand side speculations/irrationalities in the Turkish housing market during documented boom-bust period.

\subsection{The notion of the model and the key parts}

\subsubsection{The notion of the model}

This study employs a dating algorithm model. This type of algorithm is suitable when examining phenomena with minimum duration and for defining the location of turning points (i.e., bubble-bust) (Harding, 1997; Harding \& Pagan, 2002; Artis et al., 2004; Proietti, 2005; Harding \& Pagan, 2006). In our modelling approach, the bubble phenomenon is defined as a situation in which the speculative activities of market participants (i.e., individuals, investment firms, financial institutions, and builders) achieve an approximate synchronization. Consequently, during a bubble, the model expects that an irrational, synchronized, and periodic increase in a wide range of relevant variables must occur to anticipate the prevailing bubble component. Turning into more simplified explanation, when there is "simultaneously" a "large acceleration" in the rate of change of certain variables; there is a great risk that this abnormal performance is triggered or reflected by the presence of the bubble phenomenon. Following this logic, the presence of the housing bubble is confirmed once the output of the model is equal or above the threshold of 0.85 . The threshold of 0.85 is the pre-established bubble rule as proposed in the original model of Pitros and Arayici (2016).

\subsubsection{The key parts}

By using Pitros (2016) as the reference, below we are introducing the key parts of the model that are necessary for its application. Those include the: hierarchy of the variables, specific time frame of analysis, data transformation, measurement process, main multiplier, rule and finally the algorithmic model.

3.3.2.1 The hierarchy of the variables The purpose of the hierarchy of the variables in the model is to assign to each data point its proper amount of explanation over the phenomenon. With reference to Pitros and Arayici (2016), the study follows the previously established weights (see Table 2).

Here, it is worth to highlight that the income as a sole variable in the model has a weight of $0 \%$ (see, Pitros \& Arayici, 2016). The weights of importance of the variables have been identified by relying on the following question: Which variable better explains the existence of the phenomenon; if its value increases rapidly? For example, rapid speeds of growth in house prices provide a stronger assumption of the presence of a bubble than does a rapid increase in income. Following this example, if the income is increasing rapidly-positively this performance explains that any general housing market euphoria is not bubbly but rather is supported and explained by the income increases. However, income usefulness in the model is utilized when its three year moving average performance is negative/declining (i.e., using the Model II in that case). Since, whereas the more negative/declining the income is (and all other variables remain 
Table 2 Weights of the variables

\begin{tabular}{lll}
\hline Symbols & Variables & Weights \\
\hline$\alpha$ & House prices & 0.35 \\
$\beta$ & Debt-burden ratio & 0.35 \\
$\gamma$ & Gross lending & 0.20 \\
$\delta$ & Housing completions & 0.10 \\
$\varepsilon$ & Income & 0 \\
\hline
\end{tabular}

constant-positive) the even greater the probability of a bubble becomes. Turning into more details, if all bubbly variables are increasing positively-rapidly (houses prices, $\mathrm{D} / \mathrm{B}$ ratio, gross lending, and housing completions) and the variable of income is declining, then all of these positive euphoria in the market could be even more securely and sensibly explained and justified by the bubble phenomenon itself. Apart from its importance in the Model II case, the income variable is well recognized and relevantly integrated in the main multiplier of the model which is another key part and its details are seen below.

3.3.2.2 Specific time frame of analysis The specific time frame of the analysis is three years defined as the pre-specified time frame that the model takes into account when dealing with real-time data, and for each observation. Thus, when the model is applied in practice at a given time $t$, it measures the historical variation of each of the selected variables within the last three years $\left(t_{-2}, t_{-2}, t_{1}\right)$ (three-year moving average). The rationale for the selection of this time frame is explained in Pitros and Arayici (2016). In this respect, three years appears to be enough time for a bubble to develop and mature, making it relatively possible to detect, and to smooth out short-term fluctuations. The adoption of this value is also consistent with the work of Bordo and Jeanne (2002), who consider that a three-year moving average is a reasonable time frame for analysis to capture and to test property boom events.

3.3.2.3 Data transformation First, let us recall that the primary values of the variables differed in terms of scale, so that what is considered a high value for one variable can be a low value for another and vice versa. Given this asymmetrical nature of the selected data sets, the measure adopted should be one that can be used to monitor and normalize equally the magnitude of variation for each variable. For that reason, data transformation of percentage change $(\% \Delta)$ is suitable because it provides an equivalent metric and therefore lends itself to comparison when different periods are tested or current periods are examined. Most importantly, the speed of change $(\% \Delta)$ is also suitable for assessing and capturing irrational performances that caused from the interaction of herding behavior. The data transformation is applied as:

$$
\% \Delta=\frac{P\left(t_{2}\right)-P\left(t_{1}\right)}{P\left(t_{1}\right)}
$$

3.3.2.4 Measurement process The measurement process for each of the model input (variable) is inherently related to aforementioned elements: the weights, the specific time 
frame of analysis and the data transformation. As explained above, for each variable, a different weight has been established. The equation used to measure the weighted moving average for each variable (i.e., $\alpha, \beta, \gamma$, and $\delta$ ) is the following. It is worth to mention that this process is the last step for making the selected data sets suitable for integration in the algorithmic process.

Example for house price $(\alpha)$ input:

$$
W_{\alpha}=\frac{\alpha_{t-2}-\alpha_{t-1}+\alpha_{t 1}}{3 \mathrm{y}} * c
$$

where $W_{\alpha}=$ weighted variable $\alpha, \alpha_{t-2}=\Delta \%$ percentage change of $t-2, \alpha_{t-1}=\Delta \%$ percentage change of $t-1, \alpha_{t 1}=\Delta \%$ percentage change of $t 1,3 \mathrm{y}=$ three years, $c=$ respective weight of variable $\alpha$.

This process involves the calculation for the model inputs of $(\alpha)$ house price, $(\beta) \mathrm{D} / \mathrm{B}$ ratio, $(\gamma)$ gross lending and $(\delta)$ housing completions. $t_{1}$ refers to the yearly rate of change at the end of each current year, $t_{-1}$ refers to the yearly rate of change at time -1 year and $t_{-2}$ refers to the yearly rate of change at time -2 years. For instance, in order to calculate the weighted average for $\alpha$ at the end of year 2012, one should apply the yearly rate of change in 2012 as $t_{1}, 2011$ as $t_{-1}$ and 2010 as $t_{-2}$. Table 2 shows the respective weight (c) that is applicable for each of these inputs. For $(\alpha)$ this is 0.35 , for $(\beta) 0.35$, for $(\gamma)$ 0.20 and for $(\delta) 0.10$.

For instance:

$$
\begin{aligned}
& W_{\alpha}=\frac{\alpha_{t-2}-\alpha_{t-1}+\alpha_{t 1}}{3 \mathrm{y}} * 0.35 W_{\beta}=\frac{\beta_{t-2}-\beta_{t-1}+\beta_{t 1}}{3 \mathrm{y}} * 0.35 \\
& W_{\gamma}=\frac{\gamma_{t-2}-\gamma_{t-1}+\gamma_{t 1}}{3 \mathrm{y}} * 0.20 W_{\delta}=\frac{\delta_{t-2}-\delta_{t-1}+\delta_{t 1}}{3 \mathrm{y}} * 0.10
\end{aligned}
$$

As for the income variable $(\varepsilon)$, since its weight is 0 , we apply income as its simple 3 -year moving average without counting for any weight. That is in below Eq. (4):

$$
\varepsilon=\frac{\text { Income } \Delta \%_{t-2}+\text { Income } \Delta \%_{t-1}+\text { Income } \Delta \%_{t 1}}{3 \mathrm{y}} .
$$

3.3.2.5 The main multiplier With reference to the original study, Pitros and Arayici (2016), the measurement process for the main multiplier is applied using nominal values of the house price-to-income (HPI) ratio and by utilizing the below equation without accounting for any weight. Thus, the main multiplier is measured on its simple three-year moving average value and is denoted by $\lambda$, with Eq. (5) as follows:

$$
\lambda=\frac{\mathrm{HPI}_{t-2}-\mathrm{HPI}_{t-1}+\mathrm{HPI}_{t 1}}{3 y}
$$

3.3.2.6 The rule Following the quantification of the bubble rule in Pitros and Arayici (2016), this study also adopts the threshold of 0.85 . Therefore, it is recommended that values that are equal or above the selected threshold of 0.85 indicate that a high risk of a housing bubble is present and thus it is associated with positive bubble diagnosis. 
3.3.2.7 The algorithmic model The proposed model for the identification of bubbles is the following: Eqs. 6 and 7 in reference to Pitros (2016) and Pitros and Arayici (2016).

Model I:

$$
f(b)=\frac{\left[\left(X\left(w_{\alpha}+w_{\beta}+w_{\gamma}+w_{\delta}+\frac{1}{\varepsilon}\right)\right) * \lambda\right]}{\omega} \geq \rho
$$

Model II:

$$
f(b)=\frac{\left[\left(X\left(w_{\alpha}+w_{\beta}+w_{\gamma}+w_{\delta}+\sqrt{(\varepsilon)^{2}}\right)\right) * \lambda\right]}{\omega} \geq \rho
$$

where $f(b)$ equals faction of bubble, $W_{\alpha, \beta, \gamma, \delta}$ is the weighted three-year moving average of house prices, D/B ratio, gross lending and housing completions with their applicable weights. $\varepsilon$ and $\lambda$ are described in above Eqs. 4 and 5. $\omega$ is a constant taking the value of 100 whereas $\rho$ implies the bubble rule and takes the value of $0.85 . \chi$ is a constant and equals 2 . The justification for $\chi=2$ is based on the following argument. Since the phenomenon and the housing market are complex and involve an unknown number of relevant variables, the original model as proposed in Pitros and Arayici (2016) instructs us to apply it in order to smooth out, as pragmatic as possible (for the model), the unknown number of variables that determine the velocity of the market.

The original proposed method implies two models based on the proper explanations between the income and the bubble phenomenon. In this respect, Eq. (6) is used when the three-year moving average of income is positive, and Eq. (7) is employed when the three-year moving average of income is negative, although it is very rare for income to exhibit a negative performance on the basis of a three year moving average. The rationality for this relies on the view that the higher the growth of income (all other variables remain constant-positive) the less the probability of a bubble, whereas the more negative the income is (all other variables remain constant-positive) the greater the probability of a bubble. Therefore, when the three-year moving average of income is positive, its value is divided by $\frac{1}{\varepsilon}$ to reflect lower significance as income rises. However, when the three-year moving average of income is negative, we use this approach: $\sqrt{(\varepsilon)^{2}}$, to convert its negative value to a positive number, thus reflecting in the model higher significance as income declines. Via this approach, the model thus ensures that the relationship between income and the bubble phenomenon is captured proportionately.

\section{Empirical findings and implications}

The proposed model calculates the three-year moving average for each observation when dealing with bubble probabilities. Thus, it should be clarified that observations are classified by tracking the last year of each three-year moving average (Pitros \& Arayici, 2016). As seen in Table 3, the model outputs are above the threshold for the period of 2013-2017 and then declined below the threshold in 2018. Using the threshold of 0.85 for model I, our results reveal that (1) Turkish housing market was in a housing bubble during 2013-2017 period, (2) bubble busted in 2018, (3) the peak/last year of the bubble is 2017 . 
Table 3 Model results

\begin{tabular}{lll}
\hline Year & Output $^{\mathrm{a}}$ & Bubble signature \\
\hline $2007 / 2008 / 2009 \mathbf{2 0 0 9}$ & 0.66 & Negative \\
$2008 / 2009 / 2010 \mathbf{2 0 1 0}$ & 0.56 & Negative \\
$2009 / 2010 / 2011 \mathbf{2 0 1 1}$ & 0.59 & Negative \\
$2010 / 2011 / 2012 \mathbf{2 0 1 2}$ & 0.53 & Negative \\
$2011 / 2012 / 2013 \mathbf{2 0 1 3}$ & 0.95 & Positive \\
$2012 / 2013 / 2014 \mathbf{2 0 1 4}$ & 1.15 & Positive \\
$2013 / 2014 / 2015 \mathbf{2 0 1 5}$ & 1.47 & Positive \\
$2014 / 2015 / 2016 \mathbf{2 0 1 6}$ & 1.13 & Positive \\
$2015 / 2016 / 2017 \mathbf{2 0 1 7}$ & 1.49 & Positive \\
$2016 / 2017 / 2018 \mathbf{2 0 1 8}$ & 0.69 & Negative/bust \\
\hline
\end{tabular}

${ }^{\mathrm{a}}$ The Bubble rule is 0.85

Theorized in irrational bubble theory and applied in a unique data driven modelling, our results are partly in line with the findings of the existing empirical literature (see, Cagli, 2019; Iskenderoglu \& Akdag, 2019). Anecdotal evidences also suggest that market perceptions provide a ground for bubble formation (see, "Appendix 2"). The evidence has significant implications for the key market participants.

First, because Turkish bubble case study can be classified as serious given that it has been lasted for five years, we methodologically suggest that our algorithmic modelling with its components and bubble rule should follow carefully to analyze next possible housing bubble case. Among these components, however, mortgage lending variables may have special concern taken into account credit supply expansion may fuel housing speculation, generating a boom and bust in house prices (see, Mian \& Sufi, 2018). In this respect, as the component of $\mathrm{D} / \mathrm{B}$ ratio, gross lending, yearly mortgage users, and average mortgage maturity seem to be the key variables to observe housing bubble. Second, although our results document the historical bubble case for Turkey instead of a forecast, intuitions may suggest that in the event that the Turkish economy would experience some positive economic-housing market shocks along with the application of liberal lending policies in postCovid-19 global crisis period, this may result in an emerging new bubble formation in the 2020s. This can become more apparent due to the highly speculative structural characteristics of the Turkish housing market.

Third, for decisions concerning asset allocation and portfolio diversification, this historical record implies that housing may not be the best investment alternative for households/ investors aiming to protect real value of their assets in high inflation environment of Turkey. Fourth, housing producers/developers may face a serious financial risk due to bubble conditions. For example, increasing number of failed constructions firms ${ }^{1}$ may suggest that housing bubble has already some negative consequences in construction industry mostly focused on housing. Moreover, as usual, housing bubble may create some drawbacks in Turkish banking industry, issued 41.9 (35.7) billion USD credits to construction

\footnotetext{
1 The pairs of number of enterprises-real persons going-out-of-construction business are in the following during 2013-2019 period: (2013: 3365; 2650), (2014: 3171; 3064), (2015: 2717; 2731), (2016: 1185; 2964), (2017: 2510; 2908), (2018: 2289; 3461), (2019: 2389; 3820) (available at: https:// www.tobb.org.tr/, accessed on: 24 April, 2020).
} 
firms (mortgage users) in 2018. ${ }^{2}$ Probably non-transparent nature of the construction sector may increase overall bubble risks, but limited securitization in secondary mortgage market, less interconnectedness of housing with other asset classes and generally sound regulations in mortgage lending market may be classified as the major differences of the Turkish bubble case. This structure explains why Turkish bubble case did not result a systemic risk for the national economy beside some usual risk components. However, it seems difficult to predict the whole consequences of the bubble risks, the picture may become worse due to recent financial shocks in Turkish economy heightened during Covid-19 period. Finally, apparent lack of awareness on the documented boom-bust cycle in Turkish housing market suggests that market participants and policy makers should take some reasonable measures to prevent similar market failures.

\section{Conclusion}

As the leading transaction market in Europe, there has been an ongoing discussion on Turkish housing market as to whether it is performed in a speculative and irrational manner with unstable price movements. Therefore, detection of a housing bubble risk in the Turkish housing market has become a central subject of debate among researchers and market participants recently.

Turkish housing market is a relevant case study due to several reasons. Perhaps, as the most important one would be Turkey has the largest house sales volume recently in Europe. It is also an example of relatively well-developed housing market and arguably a successful story in terms of rapid market growth. In this respect, by applying the market-oriented bubble algorithmic model of Pitros and Arayici (2016), and also with reference to Bordo and Jeanne (2002), this paper examined whether there is a bubble in the Turkish housing market during the period of 2006-2018.

Our main evidence suggests that the Turkish housing market was in a bubble during 2013-2017 period. In line with the recent empirical literature, this finding gives credit to the widespread anecdotal evidences arguing a housing bubble in Turkey. Moreover, the evidence also suggests that the bubble busted in 2018. This evidence is also supported by several market data such as dramatic declines in gross mortgage lending, yearly mortgage credit users, and real house prices.

The recent housing bubble-bust period in Turkey has increased calls for policy-makers to take into account emerging housing price bubbles in their policy assessments and to develop early warning devices for bubble identification. However, as it has been showed throughout this study, the proposed method acts as an index to gage the housing bubble in Turkey at any point in time. In this approach, the housing bubble is no longer invisible until the crash, and as such can be monitored over time. Hence, given the aforementioned need from the policy makers' perspective, our approach could be used as a tool to enhance policy makers' knowledge toward the early identification of housing bubbles. This could

\footnotetext{
${ }^{2}$ The pairs of non-performing loans (NPL) ratios in construction and mortgage loans are in the following during 2013-2019 period: (2013: 4.20; 0.61), (2014: 4.12; 0.49), (2015: 3.71; 0.46), (2016: 3.70; 0.54), (2017: 3.45; 0.42), (2018: 5.35; 0.52) and (2019: 9.82; 0.63) (available at: http://ebulten.bddk.org.tr/ ABMVC/tr/Gosterim/Gelismis\#, accessed on, 24 April, 2020). NPL ratio in mortgage lending may not be a sole representative measure of housing finance risks in Turkey due to high volume of installment sales. Lack of data in credit-holders NPL ratio in construction lending makes difficult to drive some general conclusions for overall NPL level. However, dramatically rising NPL ratio in construction loans in 2018-2019 may explain the accumulated bubble-related risks in construction firms and their lenders.
} 
considerably help policy makers to develop relevant policies with the purpose of "disinflating" the bubble once early spotted (during its first 3 years) and thus minimizing/avoiding the well-known severe consequences of the bubble-bust. The same assessment approach could be also taken by credit institutions for applying a conservative lending behavior during early bubble diagnosis and thus contributing toward the disinflation of housing prices.

\section{Appendix 1: Data Information (2006-2018)}

\section{Symbols Name \& unit of measure \& frequency \& scope Data source, variable description \& construction}

$\alpha \quad$ House Prices; [TL]; Annual; National Level Source: Reidin, TurkStat and our calculations. (1) Aggregate level year-end unit house price data are retrieved from Reidin. (2) Aggregate level year-end average floor area data (sq-m) calculated by authors based on TurkStat data. Description: TL/sq-m, nominal, aggregate level. Construction: Nominal house prices are computed through multiplying year-end unit house price (TL/sq-m) and average floor area (sq-m) data. Based on this house price data, we also calculated HPI ratio (see below $\boldsymbol{\lambda}$ )

Debt Burden (D/B); [Ratio]; Annual; National Level

Gross Lending; [TL]; Annual; National Level

Source: (1) Gross lending and yearly credit users data retrieved from TBAT. (2) Average maturity of housing loans data provided by Garanti Mortgage BBVA. (3) Median income last decile (top 10\%) data is retrieved from TurkStat. Description: Mortgage payment as a percentage of the mean take home pay for an average buyer. All below variables used as their nominal values except average maturity of housing loans. This is the annual number representing the average maturity in years. Construction: $\mathrm{D} / \mathrm{B}$ ratio is calculated through the following steps:

(1) D/B Ratio = Average Mortgage Payment/ Median Income Last Decile (top 10\%)

(2) Average Mortgage Payment = Average Mortgage Debt/Average Maturity of Housing Loans

(3) Average Mortgage Debt = Gross Lending/ Yearly Credit Users

$\delta \quad$ Housing Completions; [unit]; Annual; National Level

Source: TBAT. Description: Gross, nominal, TL denominated mortgage loan volume

Source: CBRT. Description: Occupancy permit involving two and more dwelling residential buildings (number of dwelling units; private enterprise)

$\boldsymbol{\varepsilon} \quad$ Income; [TL]; Annual; National Level

Source: TurkStat. Description: Median income last decile (top 10\%), TL, nominal 


\begin{tabular}{lll}
\hline Symbols & Name \& unit of measure \& frequency \& scope & Data source, variable description \& construction \\
\hline$\lambda$ & HPI; [Ratio]; Annual; National Level & Source: Reidin, TurkStat and our calculations. \\
& & Description: $\alpha$ and $\varepsilon$ variables employed as \\
& TL, nominal, and aggregate level. Hence, \\
& income is the median income last decile (top \\
& $10 \%)$. Construction: House Price-to-Income \\
& Ratio = House Price/Income \\
\hline
\end{tabular}

D/B Ratio, debt burden ratio; HPI, house price-to-income ratio; TL; sq-m, square meter, Turkish Lira; CBRT, Central Bank of Republic of Turkey; TBAT, The Bank Association of Turkey, TurkStat, Turkish Statistical Institute.

\section{Appendix 2: Turkish housing market: overview-supply/demand side speculations}

Below, we provide an overview about Turkish housing market with the focus of her supply/ demand side speculative/irrational nature that eventually resulted in a boom-bust period recently as documented in this paper.

\section{Overview of Turkish housing market}

With the 59\% ownership ratio as of 2019, Turkey has an ownership housing market with a market-based housing supply system. Access to formal housing finance is generally low in Turkey. For example, as of 2019 while Poland and France have 3,487 EUR and 20,547 EUR total outstanding residential loans per capita, respectively, Turkey has 1,736 EUR. Despite high annual interest rates for new residential loans, such as $12.1 \%, 19.3 \%$ and $18 \%$ during 2017, 2018, and 2019, housing demand, supply, and credit volume figures suggest that housing market has showed a significant development in Turkey. For example, while total outstanding residential loan volume has increased from 16.4 billion EUR as of 2008 to 29.9 billion EUR as of 2019, occupancy permit showed $56.4 \%$ increase during 2009 and 2019 period. During same period, the number of transactions has increased $216 \%$ and eventually reached to 1.3 million as of 2019 (see, Hypostat, 2020; TurkStat, 2020). However, thanks to ongoing economic shocks in Turkish economy, the market has experienced a visible crisis in recent years. For example, average amount of granted mortgage has declined from 22.530 EUR as of 2015 to 13,121 EUR as of 2019. Total outstanding residential loans to GDP ratio also declined from $36.4 \%$ to $30.9 \%$ during same period. On the other hand, while building permits, as an indicator of future housing supply, showed $77.7 \%$ decline during 2017 and 2019 period, average amount of a mortgage granted showed 41.8\% decline during 2015 and 2019 period (see, Hypostat, 2020).

Overall, this picture may intuitively suggest a declining market structure. Below, we briefly speculate possible supply/demand side irrational/speculative components of the recent boom and bust period of the Turkish housing market.

\section{Demand side speculation and irrationalities}

However, it eventually partially transforms another form of irrationality, housing demand has strong fundamentals in Turkey due to both demographic (i.e., increasing population, 
immigration etc.) and economic factors. From economic perspective, thanks to steadily rising inflation and almost permanent interest/exchange rate shocks in last decade, Turkish households perceive that housing would be a safe haven for eroding purchasing power of Turkish Lira. This perception contributed to recent demand/supply-side speculative activities in the Turkish housing market. However, data suggest that income growth did not fully support recent dramatic increases in house price. In this respect, while nominal Residential Property Price Index of CBRT increased 162\%, 196\%, 110\% and 172\% in Turkey, Istanbul, Ankara, and Izmir respectively, GDP per capita in terms of USD showed a $13.3 \%$ decline during 2010 and 2019 period (see, CBRT, 2020; TurkStat, 2020). In addition to declining income level, its fairly unequal distributed nature also implies an acute housing affordability crisis in Turkey, rather than a strong fundamental for the house price inflation. Coskun (2020) provides evidence that beside macroeconomic instabilities, distorted interest rates and short average mortgage maturity, poverty and unequal income/wealth distributions are the main reasons of the Turkish housing affordability crisis specifically heightened in the metropolitan areas such as in Istanbul.

Another sign of demand-side irrationality would be the increases in overall mortgage volume and outstanding mortgage users are $231 \%$ and $111 \%$ respectively during 2010 and 2019 period. After such a dramatic increase, the number of outstanding mortgage users has reached to 2.28 million persons. Moreover, because of the rising interest rates and access to mortgage problems, the percentage of non-institutional housing finance has also steadily increased in national market despite its explicit risks.

\section{Supply side speculation and irrationalities}

Because a large portion of developments is funded by consumers through advance deposits/presales in many emerging countries involving Turkey (Chiquier, 2009), housing developers have also a special role in the rising speculation/irrationality in the Turkish housing market. Speculative housing supply has its own "rational" roots in Turkey. The first contributing element of the supply-side speculation would be booming numbers of developers in Turkey. Turkish construction industry is highly competitive and one of the largest in Europe. According to European Construction Industry Federation, ${ }^{3}$ the number of construction enterprises in Turkey has increased from 200,000 as of 2012 to 350,000 as of 2017 and then declined to 330,000 in both 2018 and 2019. Taken also into account the ratio of failed/newly established construction entities is 32\% during 2000-2019 period, we may conclude that construction is a highly risky business in Turkey. ${ }^{4}$ Living in such a survival of the fittest environment, developers have mainly focused on high profit during the rising period of the market.

However, it seems that the most important supply-side irrationality is the supply increases despite observable oversupply in the market. This implies that supply side of the Turkish housing market is probably the subject of overoptimistic and irrational

\footnotetext{
3 Available at: http://sefifrance.fr/images/documents/fieckeyfig2012.pdf; https:/www.wko.at/branchen/ gewerbe-handwerk/bau/fiec-key-figures-2019-activity-2018.pdf; https://pedmede.gr/wp-content/uploads/ 2018/07/07_FIEC_KF2018.pdf http://www.fiec.eu/application/files/9016/0190/8790/FIEC_Key_Figures_ Edition_2020.pdf (accessed on: 9 October, 2020).

4 Authors' calculations through the data of The Union of Chambers and Commodity Exchange of Turkey (Available at: https://www.tobb.org.tr/BilgiErisimMudurlugu/Sayfalar/KurulanKapananSirketistatistikleri. php, accessed on: 9 October, 2020).
} 
behaviors. In this respect, we calculate cumulative excess supply is 1.1 million units during 2010-2019 period. ${ }^{5}$ But, despite high level of excess supply, overall construction permit is 8.3 million units in this period.

Excess supply and also perceived profit-making opportunity in the housing market have forced constructors to develop aggressive marketing strategies in last decade in Turkey. This is another sign of speculation with some very interesting features. It was typically observed that local housing projects focus to sell their units through prime-time national television campaigns. In addition to the mainstream channels, housing marketing campaigns have also utilized some visual (i.e., billboard, taxi, cinema etc. ${ }^{6}$ ) and printed advertisement channels (i.e., freely available brochures in newspapers and in airports). ${ }^{7}$ Anecdotal evidences also suggest that construction firms use highly creative marketing strategies such as buy four and get one free houses ${ }^{8}$ and buy a house with a free luxury car. ${ }^{9}$ As the usual market practices in some non-bank housing credit channels, it has observed that some developers have even applied 0\% down payment with a highly extended payment period and irrationally low interest rates ${ }^{10}$ implying an inherent tricky pricing structure with some discount games. Although nationwide house price indexes may not totally involve and timely reflect the real market sentiment/practice, anecdotal evidences suggest that increasing volume of unsold housing units has resulted large price discounts specifically in cash transactions. Moreover, major producers have collectively launched some national level marketing campaigns as a group action to sell their oversupply. ${ }^{11}$ All these highly unusual marketing strategies may imply a possible speculative feature of the supply side dynamics.

\footnotetext{
${ }^{5}$ However, it is difficult to predict a precise housing oversupply in new residential markets in Turkey due to constraints of the data, we find new housing oversupply as the difference between occupancy permit (as the indicator of new -readily available- housing supply) and sold new residential units (as the realized demand indicator) (see, for the data: https://biruni.tuik.gov.tr/medas/?kn=73\&locale=tr; see, for the methodology: https://www.tmb.org.tr/arastirma_yayinlar/tmbbulten_temmuz2019.pdf, accessed on: 16.10.2020).

${ }^{6}$ Even, some websites provide information on how to establish a "guerilla marketing" strategies for selling houses (i.e.,, see, https:/goktugbeser.com/emlak-gayrimenkul-gerilla-pazarlama-ornekler-uygulamalar/ (accessed on: 4 August, 2018).

7 During this period, constructors/developers have become the leading customers of the Turkish advertisement industry. According to the data of Advertisement Association of Turkey, media and advertisement expenditure of Turkey is 2.9 billion USD as of 2017 and construction \& decoration is the leading industry with cosmetic \& personal care industry in terms of spending on the advertisement (Available at: http:// rd.org.tr/www/rd/assets/doc/RD-medya-ve-reklam-yatirimlari-2017-Raporu.pdf, accessed on: 4 August, 2018). Interestingly, Colak (2018) indicates that media behaves as movie star to the developers by making their news by even using special paparazzi teams.

8 Available at: https://www.emlakjet.com/haber/haber/hane-plus-4-ev-alana-1-ev-bedava-1 (accessed on: 4 August, 2018).

9 Available at: https://www.milliyetemlak.com/dergi/soyak-konforia-araba-hediye-ediyor/ (accessed on: 4 August, 2018).

10 Some housing marketing campaigns also involve $0 \%$ interest rates for the back payment period despite very high annual rate of interest in Turkey (see, https://www.hurriyetemlak.com/emlak-yasam/faizsizkonut-satisi/, accessed on 4 August, 2018).

11 After some house selling campaigns during 2016, major private housing developers offered $20 \%$ discount for their unsold housing units in 2018. Moreover, TOKI, as a central government agency, also provides probably a regular $20 \%$ discount for her house buyers (Available at: http://htemlak.haberturk.com/ kampanyali-konut-projeleri/haber/1275085-gyoderden-56-bin-konutta-kacirilmayacak-firsat; https://www. hurriyetemlak.com/emlak-yasam/konut-fiyatlarina-indirim-yapan-firmalar/; https:/www.toki.gov.tr/haber/ tokiden-esnek-odeme-ile-yuzde-20-indirim-kampanyasi, accessed on: 4 August, 2018).
} 


\section{Regulatory reaction and affordability crisis}

Finally, it may be interesting to note that increasing speculation in the housing market did not face a satisfactory regulatory response despite declining housing ownership ratio in last decade in Turkey. Declining housing ownership ratio may be also accepted as one of the signs/results of the speculative nature of the Turkish housing market. In this respect, while house sales, increased from 607,098 as of 2010 to $1,348,729$ as of 2019 , country level housing ownership ratio has slightly declined from $60 \%$ as of 2010 to $59 \%$ as of 2018 . But more interestingly, housing ownership ratio for lower income groups, based on below $60 \%$ of the median income criterion, has significantly declined from 58.8 to $52.1 \%$ during the same period.

Therefore, as an interesting dimension of the recent housing boom-bust period in Turkey, significantly rising house prices/sales and demand/supply side speculations eventually resulted in a housing affordability crisis specifically in lower income groups (see, Coskun, 2020).

Acknowledgements The authors are grateful to Garanti BBVA Mortgage (Murat Atay) and Reidin for their data support.

\section{References}

Anundsen, A. K. (2019). Detecting imbalances in house prices: What goes up must come down? The Scandinavian Journal of Economics, 121(4), 1587-1619.

Artis, M., Marcellino, M., \& Proietti, T. (2004). Dating business cycles: A methodological contribution with an application to the euro area. Oxford Bulletin of Economics and Statistics, 6(4), 537-565.

Ayuso, J., \& Restoy, F. (2003). House prices and rents: An equilibrium approach. Working paper no. 0304, Banco de España.

Barrell, R., Kirby, S., \& Riley, R. (2004). The current position of UK house prices. National Institute Economic Review, 189(1), 57-60.

Baum, A., \& Hartzell, D. (2012). Global property investment: Strategies, structure, and decisions. Wiley.

Bell, A. R., Brooks, C., \& Killick, H. (2018). The first real estate bubble? Land prices and rents in medieval England C. 1300-1500. March 26. Available at SSRN: Retrieved May 31, 2019, from https://ssrn.com/ abstract $=3149574$.

Black, A., Fraser, P., \& Hoesli, M. (2006). House prices, fundamentals and bubbles. Journal of Business Finance \& Accounting, 33, 1535-1555.

Bordo, M.D., \& Jeanne, O. (2002). Boom-busts in asset prices, economic stability and monetary policy. Working paper 8966. National Bureau of Economic Research.

Bourassa, S. C., Hoesli, M., \& Oikarinen, E. (2019). Measuring house price bubbles. Real Estate Economics, 47(2), 534-563.

Brée, D., \& Joseph, N. (2013). Testing for financial crashes using the log-periodic power law model. International Review of Financial Analysis, 30, 287-297.

Budd, C. H. (2011). Finance at the threshold: Rethinking the real and finance economics. Gower Publishing.

Cagli, E. C. (2019). Explosive behavior in the real estate market of Turkey. Borsa Istanbul Review, 19(3), $258-263$.

Cadil, J. (2009). Housing price bubble analysis: Case of the Czech Republic. Prague Economic Papers, 1, $38-47$.

Cameron, G., Muellbauer, J., \& Murphy, A. (2006). Was there a British House Price Bubble? Evidence from a regional panel. Working paper series (p. 142). Department of Economics, University of Oxford.

Case, K. E., \& Shiller, R. J. (2003). Is there a bubble in the housing market? Brookings Papers on Economic Activity, 2, 299-362.

CBRT (Central Bank of Republic of Turkey). House Price Index (Turkey, Istanbul, Ankara, and Izmir) and CPI Data. Retrieved October 31, 2020, from https://evds2.tcmb.gov.tr/index.php?/evds/serieMarket. 
Cerutti, E., Dagher, J., \& Dell'Ariccia, G. (2015). Housing finance and real-estate booms: A cross-country perspective. IMF Staff discussion note. June. Retrieved September 12, 2019, from https://www.imf. org/external/pubs/ft/sdn/2015/sdn1512.pdf.

Chen, R. D., Gan, C., Hu, B., \& Cohen, D. A. (2013). An empirical analysis of house price bubble: A case study of Beijing housing market. Research in Applied Economics, 5(1), 77-97.

Chen, Y., Phillips, P. C., \& Yu, J. (2017). Inference in continuous systems with mildly explosive regressors. Journal of Econometrics, 201(2), 400-416. https://doi.org/10.1016/J.JECONOM.2017.08.016

Chiquier, L. (2009). Construction finance in emerging economies. In L. Chiquier \& M. ve Lea (Eds.), Housing finance policy in emerging markets (pp. 159-173). Washington D.C.: The World Bank.

Chung, H. S., \& Kim, J. H. (2004). Housing speculation and housing price bubble in Korea. Working paper 04-06, KDI 2004.

Colak, O. F. (2018). Konut Balonu Tartışması. 23 February. Dunya Newspaper. Retrieved October 21, 2020, from https://www.dunya.com/kose-yazisi/konut-balonu-tartismasi/404453.

Coskun, Y. (2011). The global financial crisis and the Turkish housing market: Is there a success story? Housing Finance International, 25(3), 6-14.

Coskun, Y. (2015). Türkiye'de Konut Finansmanı: Sorunlar ve Çözüm Önerileri. Publication No: 310. The Banks Association of Turkey. April. Istanbul.

Coskun, Y., \& Jadevicius, A. (2017). Is there a housing bubble in Turkey? Real Estate Management and Valuation, 25(1), 48-73.

Coskun, Y., Seven, U., Ertugrul, H. M., \& Alp, A. (2020). Housing price dynamics and bubble risk: The case of Turkey. Housing Studies, 35(1), 50-86.

Coskun, Y. (2020). Measuring homeownership affordability in emergent market context: An exploratory analysis for Turkey. International Journal of Housing Markets and Analysis. https://doi.org/10. 1108/IJHMA-04-2020-0033.

da Nóbrega Besarria, C., Paes, N. L., \& Silva, M. E. A. (2018). Testing for bubbles in housing markets: Some evidence for Brazil. International Journal of Housing Markets and Analysis, 11(5), 754770. https://doi.org/10.1108/IJHMA-08-2017-0075.

Duran, H. E., \& Özdoğan, H. (2020). Asymmetries across regional housing markets in Turkey. The Journal of Economic Asymmetries, 22, e00178.

Erol, I. (2015), “Türkiye'de konut balonu var mı? konut sektörü kapitalizasyon oranları analizi, in Özçelik, E. and Taymaz, E (Eds.), Türkiye Ekonomisinin Dünü, Bugünü Yarını, Yakup Kepenek’e ve Oktar Türel'e Armağan, İmge Kitabevi Yayınları (pp. 323-344).

Geraskin, P., \& Fantazzini, D. (2011). Everything you always wanted to know about log periodic power laws for bubble modeling but were afraid to ask. European Journal of Finance, forthcoming. Retrieved June 29, 2019, from http://ssrn.com/abstract=1752115.

Girouard, N., Kennedy, M., Noord, P. V. D., \& André, C. (2005). Recent house price developments: The role of fundamentals. OECD Economic Outlook, 78, 193-234.

Glaeser E., \& Gyourko J. (2007). Arbitrage in housing markets. NBER Work. Pap. 13704.

Glaeser, E. L. (2013). A Nation of Gamblers: Real estate speculation and American history. Policy Briefs. May. Taubman Center, Harvard Kennedy School. Retrieved May 29, 2019, from https:// www.hks.harvard.edu/sites/default/files/centers/taubman/files/ely.pdf.

Greenspan, A. (2015). Comments and discussion, Brookings papers on economic activity, Spring (pp. 197-206).

Grybauskas, A., \& Pilinkienė, V. (2018). Real estate market stability: Evaluation of the metropolitan areas using factor analysis. Engineering Economics, 29(2), 158-167.

Gustavsson, M., Levén, D., \& Sjögren, H. (2016). The timing of the popping. Using the log-periodic power law model to predict the bursting of bubbles on financial markets. Financial History Review, 23, 193-217.

Haines, C., \& Rosen, R. J. (2007). Bubble, bubble, toil and trouble. Economic Perspectives, 31(1), $16-35$.

Harding, D. (1997). The definition, dating and duration of cycles. Paper presented to the Melbourne Institute conference on business cycle: Policy and analysis.

Harding, D., \& Pagan, A. R. (2002). Dissecting the cycle: A methodological investigation. Journal of Monetary Economics, 49(2), 365-381.

Harding, D., \& Pagan, A. (2006). Synchronization of cycles. Journal of Econometrics, 132(1), 59-79.

Himmelberg, C., Mayer, C., \& Sinai, T. (2005). Assessing high house prices: Bubbles, fundamentals and misperceptions. Journal of Economic Perspectives, 19(4), 67-92.

Hlaváček, M., \& Komárek, L. (2009). Housing price bubbles and their determinants in the Czech Republic and its regions. Working paper series of the Czech National Bank (CNB).

Holcombe, R. G., \& Powel, B. (2009). Housing America: Building out of a crisis. Transaction Publishers. 
Hott, C. (2012). The influence of herding behavior on house prices. Journal of European Real Estate Research, 5(3), 177-198. https://doi.org/10.1108/1753926121128204

Hou, Y. (2009). House price bubbles in Beijing and Shanghai? A multi-indicator analysis. International Journal of Housing Markets and Analysis, 3(1), 17-37.

HypoStat. (2019). A review of Europe's mortgage and housing markets. September. European Mortgage Federation.

HypoStat. (2020). A review of Europe's mortgage and housing markets. November. European Mortgage Federation.

IMF. (2017). IMF country report no. 17/33. February.

Iskenderoglu, O., \& Akdag, S. (2019). Türkiye'de Reel Konut Fiyatlarında Balonların Varlığı Üzerine Uygulamalı Bir Analiz. Business and Economics Research Journal, 10(5), 1085-1093.

Joebges, H., Dullien, S., \& Márquez-Velázquez, A. (2015). What causes housing bubbles? A theoretical and empirical inquiry. November. Working paper (Macroeconomic Policy Institute). Retrieved March 15, 2019, from https://www.boeckler.de/pdf/p_imk_study_43_2015.pdf.

Kohn, J., \& Bryant, K. S. (2010). An econometric interpretation of the recent US housing boom. Research in Business and Economics Journal.

Krainer, J., \& Wei, C. (2004). House prices and fundamental value. FRBSF economic letter, no. 27, October.

Lai, R. N., \& Van Order, R. A. (2010). Momentum and house price growth in the United States: Anatomy of a bubble. Real Estate Economics, 38(4), 753-773. https://doi.org/10.1111/j.1540-6229.2010.00282.x

Mao, G., \& Shen, Y. (2019). Bubbles or fundamentals? Modeling provincial house prices in China allowing for cross-sectional dependence. China Economic Review, 53, 53-64.

Muellbauer, J., \& Murphy, A. (2008). Housing markets and the economy: The assessment. Oxford Review of Economic Policy, 24(1), 1-33.

Mian, A., \& Sufi, A. (2018). Credit supply and housing speculation. Working paper no. 24823. NBER.

Mueller, G. R., \& Pevnev, A. (1997). An analysis of rental growth rates during different points in the real estate cycle. Paper presented at the American Real Estate Society Annual Meeting, Sarasota, FL.

Orrell, D., \& McSharry, P. (2009). System economics: Overcoming the pitfalls of forecasting models via a multidisciplinary approach. International Journal of Forecasting, 25(4), 734-743.

Pitros, C. (2016). How to identify UK housing bubbles a decision support model. Ph.D. dissertation. April. The School of the Built Environment, University of Salford, UK. Retrieved September 13, 2018, from https://core.ac.uk/download/pdf/46569444.pdf.

Pitros, C., \& Arayici, Y. (2016). How to identify housing bubbles? A decision support model. International Journal of Housing Markets and Analysis, 9(2), 190-221. https://doi.org/10.1108/ IJHMA-01-2015-0002

Pitros, C., Coşkun, Y., \& Arayici, Y. (2016) Is there a bubbly euphoria in the Turkish housing market? TEK conference. October 20-22. Bodrum, Turkey.

Proietti, T. (2005). New algorithms for dating the business cycle. Computational Statistics \& Data Analysis, 49(2), 477-498.

Shiller, R. (1992). Market volatility. MIT Press.

Stiglitz, J. E. (1990). Symposium on bubbles. The Journal of Economic Perspectives, 4(2), 13-18.

Tajani, F., Morano, P., Saez-Perez, M. P., Di Liddo, F., \& Locurcio, M. (2019). Multivariate dynamic analysis and forecasting models of future property bubbles: Empirical applications to the housing markets of Spanish metropolitan cities. Sustainability, 11(13), 3575.

The Banks Association of Turkey (TBAT). (2012). Developing capital market solutions for the mortgage market in Turkey. Retrieved May 17, 2019, from https://www.tbb.org.tr/en/Content/Upload/Dokuman/ 40/Eng_-_final_report_-_sanitized.pdf.

Tsai, I. C. (2019). European house price deviation: Infectivity and the momentum effect. Economic Research-Ekonomska Istraživanja, 32(1), 1521-1541.

TurkStat. (2020). Retrieved October 31, 2020, from http://www.tuik.gov.tr/PreHaberBultenleri.do?id=24918.

Wang, J., Koblyakova, A., Tiwari, P., \& Croucher, J. S. (2018). Is the Australian housing market in a bubble? International Journal of Housing Markets and Analysis, 13(1), 77-95. https://doi.org/10.1108/ IJHMA-03-2017-0026

Weeken, O. (2004). Asset pricing and the housing market. Bank of England Quarterly Bulletin, Spring (pp. 32-41).

Zhou, W. X., \& Sornette, D. (2003). 2000-2003 real estate bubble in the UK but not in the USA. Physica A: Statistical Mechanics and its Applications, 329(1-2), 249-263.

Publisher's Note Springer Nature remains neutral with regard to jurisdictional claims in published maps and institutional affiliations. 